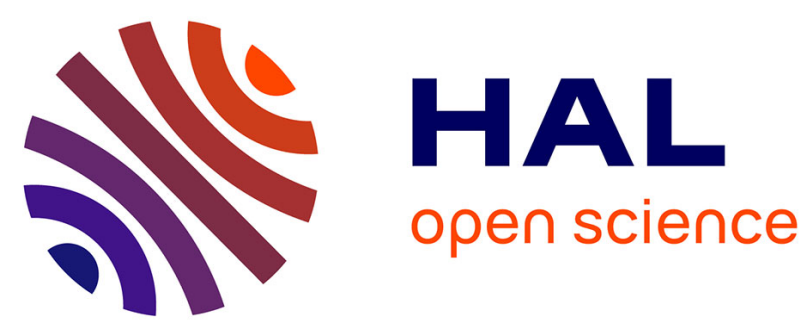

\title{
Nomenclatural note on the homonymy between the octocoral genus Dendrobrachia Brook 1889 and the entoproct phylum Dendrobrachia Xian-Guan, Bergström, Xio-Ya and Jie 2006
}

Eric Pante

\section{To cite this version:}

Eric Pante. Nomenclatural note on the homonymy between the octocoral genus Dendrobrachia Brook 1889 and the entoproct phylum Dendrobrachia Xian-Guan, Bergström, Xio-Ya and Jie 2006. Zootaxa, 2016, 4107 (4), pp.598-598. 10.11646/zootaxa.4107.4.8 . hal-01390721

\section{HAL Id: hal-01390721 \\ https://hal.science/hal-01390721}

Submitted on 4 Nov 2016

HAL is a multi-disciplinary open access archive for the deposit and dissemination of scientific research documents, whether they are published or not. The documents may come from teaching and research institutions in France or abroad, or from public or private research centers.
L'archive ouverte pluridisciplinaire $\mathbf{H A L}$, est destinée au dépôt et à la diffusion de documents scientifiques de niveau recherche, publiés ou non, émanant des établissements d'enseignement et de recherche français ou étrangers, des laboratoires publics ou privés. 
Zootaxa 4107 (4): 598-598.

CORRESPONDANCE

Nomenclatural note on the homonymy between the octocoral genus Dendrobrachia Brook 1889 and the entoproct phylum Dendrobrachia Xian-Guan, Bergström, Xio-Ya and Jie 2006

\section{ERIC PANTE}

LIENSs Laboratory, UMR 7266 CNRS-University of La Rochelle, 2 rue Olympe de Gouges, 17000 La Rochelle, France

Dendrobrachia was proposed by Xian-Guan et al. (2006) as the name of a new phylum of entoproct-like animals from the Lower Cambrian (Yunnan Province, China). This name was however preoccupied by the octocoral Dendrobrachia Brook 1889, which position within the subclass Octocorallia is currently uncertain (Opresko and Bayer 1991; Berntson et al. 1999, 2001). Based on the principles of homonymy and priority (Articles 52 and 23, respectively; ICZN 1999), a substitute name for the entoproct Dendrobrachia is necessary, and I propose Dendrobrachion (based on the Greek brachion, for arm).

Keywords

Dendrobrachia, Coelenterata

References

Berntson, E.A., Bayer, F.M., McArthur, A.G. \& France, S.C. (2001) Phylogenetic relationships within the Octocorallia (Cnidaria: Anthozoa) based on nuclear 18s rRNA sequences. Marine Biology, 138 (2), 235-246.

http://dx.doi.org/10.1007/s002270000457

Berntson, E.A., France S.C., Mullineaux, L.S. (1999) Phylogenetic relationships within the Class Anthozoa (Phylum Cnidaria) based on nuclear 18s rDNA sequences. Molecular Phylogenetics and Evolution, 13 (2), 417-433.

http://dx.doi.org/10.1006/mpev.1999.0649

Brook, G. (1889) Report on the Antipatharia. Report of the Scientific Results of the Voyage of H.M.S. Challenger, 32 (Zoology), 1-222, pls. 1-15.

ICZN (1999) International Code of Zoological Nomenclature. Fourth Edition. International Trust for Zoological Nomenclature, London, $306 \mathrm{pp}$.

Opresko, D. \& Bayer, F. (1991) Rediscovery of the enigmatic Coelenterate Dendrobrachia (Octocorallia: Gorgonacea) with descriptions of two new species. Transactions of the Royal Society of S. Australia, 115 (1), 1-19.

Xian-Guang, H., Bergström, J., Xiao-Ya, M. \& Jie, Z. (2006) The Lower Cambrian Phlogites Luo \& Hu re-considered. GFF, 128 (1), 47-51.

http://dx.doi.org/10.1080/11035890601281047

DOI: http://dx.doi.org/10.11646/zootaxa.4107.4.8 